\title{
Marxists Internet Archive Takedown
}

\author{
Tai Neilson
}

Administrators of the Marxists Internet Archive (MIA) removed the texts based on Marx and Engels' Collected Works $(\underline{M E C W})$ from their website on May 1, 2014. The works were taken down in compliance with a directive from the publisher Lawrence and Wishart (L\&W) that claims ownership of the 50 volume collection. L\&W's directive sought to retract these works - works by, arguably, two of the most important radical intellectuals that have been deceased for more than a century - from free public access. This incident exposes continuing conflicts at the intersection of intellectual property, labor and digital technologies. More specifically, it demonstrates how legal and ideological discourses of ownership and authorship are mobilized to benefit capital at the expense of public knowledge and even authors themselves. L\&W's claim over these works stem from MECW's status as a derivative work. An analysis of the history of these works reveals that they are the product of many types of labor including the work done by Marx and Engels, academics, students, translators, publishers and online volunteers. This paper asks: how have economic and political interests shaped discourses of authorship and intellectual property that allow L\&W to assert ownership over some of Marx and Engels' works? In what ways do new production practices and technological changes serve to challenge L\&W's claim? And, what alternatives to the current intellectual property regime can address the needs of knowledge producers and the public?

The two institutions involved in the controversy over MECW represent different models of publishing. MIA uses the internet to facilitate collaborative production and the free distribution of information. It is a nonprofit, public archive that began in 1990 and is maintained through volunteer labor (http://marxists.org/admin/intro/ index.htm 2014). The vast majority of the material in the archive is drawn from the public domain, and all MIAcreated content is held under Creative Commons license, which permits users to freely "copy, distribute and/or modify" the material (http://marxists.org/admin/intro/index.htm 2014). Collaborative, online projects serve as alternatives to market mechanisms for distributing information goods. However, organizations like MIA, which draw on voluntary, unpaid contributions and publish information online, still face operating costs and limitations based on intellectual property law.

The sustainability of publishing models that rely solely on voluntary contributions is called into question by ongoing operating costs and legal challenges. To try to cover some operating costs MIA prints and sells a small selection of books. Voluntary organizations are unlikely to have the resources to compete with more traditional publishers when they are faced with litigation. MIA has maintained a policy of compliance with what it terms "bourgeois legality." More generally, this policy has meant limiting the website's content to texts that are already in the public domain. MIA has also complied with demands to remove material from its archive. In 2008 the archive's administrators removed sections of Antonio Gramsci's (1891-1937) Selections from the Prison Notebooks at the behest of L\&W who claim ownership of the works translated by Quintin Hoare (http://marxists.org/archive/ gramsci/index.htm 2014). This set a precedent for the case examined in this paper. Content based on the $\underline{\mathrm{MECW}}$ was removed when $\mathrm{L} \& \mathrm{~W}$ declared that the material was being distributed in breach of copyright (http://marxists. org/archive/marx/works/cw/index.htm 2014). In both cases, L\&W's claim to ownership relied on the material's status as derivative work. In other words, L\&W claims to own the particular translation or compilation of the works, and in both cases MIA's administrators removed the material without legal recourse.

L\&W represents a more traditional model of publishing and labels itself an independent British publisher. They were founded in 1936 as a partnership between Martin Lawrence, the British Communist Party's press, and Wishart Ltd, a leftist publisher. L\&W publishes "literature, drama and poetry, as well as political economy, working- 
class history and the classics of Marxism" (http://www.lwbooks.co.uk/about.html 2014). In a response to criticism directed at the company for directing the takedown of MECW material, L\&W note that:

As small radical publishers ourselves, we are of course familiar with the complexity and difficulty of publishing in the digital age. The debate over MECW is a proxy for what L\&W have been continuously grappling with for the last two decades: how to run a sustainable radical publishing company in this new context (http://www.lwbooks.co.uk/collected_works_ statement.html 2014).

As L\&W's response indicates, the conflict over MECW highlights the cleavages between two models of publishing and represents a microcosm of wider debates about intellectual property, labor and digital media.

L\&W invokes the body of intellectual property law related to copyright to lay claim to versions of the works of Marx and Engels. Copyright is a legal apparatus that affords the producer of a creative work the rights to publish or sell their product, but authors can also transfer this right to third parties such as publishers (Foster and Shook 1989). Increasing recognition that the production of knowledge is a collective and ongoing process is placing pressure on copyright law and its basis in romantic understandings of the individual author. Further, the role of patents and copyrights as "social innovations designed to create artificial scarcities where none existed naturally" is made even more palpable as the internet can facilitate the proliferation of information (Arrow 1996: 125). By tracing the material and discursive history of these legal mechanisms it is possible to show how a cultural and legal formation as recent as intellectual property has established itself as a seemingly natural and eternal social good.

\section{Histories of Intellectual Property}

The legal and ideological apparatus of copyright has been subjected to criticism on historical and theoretical grounds. Michel Foucault spurred a number of historical critiques of the concept of authorship and intellectual property with his influential (1977) essay "What is an Author?” In the essay, Foucault argues that the author's function is a product of "the modes of circulation, valorization, attribution, and appropriation" of discourses that operate in a particular society (Foucault 1977: 137). The intellectual property laws that have been enacted in the West establish their legitimacy through concepts of the author, individual creativity and private property. These discourses were produced in the interest of writers, publishers and political rulers in Europe in the eighteenth century. Two different, but related, tracks to intellectual property rights emerged in Western Europe at the end of the eighteenth century. In continental Europe, moral rights for authors draw on idealist philosophy to justify economic and extra-economic rights for authors. In the Anglo-American context, Lockean and utilitarian approaches established a legal tradition of intellectual property. In both cases, the interests of publishers, states and writers shaped the discourses and legal apparatuses of intellectual property.

In continental Europe, writers and artists vied with commonly held interpretations of the arts as crafts that merely drew on preexisting ideas and whose products, in turn, constituted part of the public domain. In The Author, Art, and the Market (1994), Martha Woodmansee demonstrates how German poets and philosophers set out to produce a new concept of the "author" with monopoly rights over the products of their labor. Writers began to challenge existing pedagogical and utilitarian conceptions of art, suggesting that art has an intrinsic value. They coupled this notion with an emphasis on the individual genius of the artist (Woodmansee 1994: 30, 39). These writers had personal stakes in representing art as an intrinsically valuable endeavor and securing the right to their literary creations as property. This was made more pressing as Germany shifted from a patrimonial economic model of artistic production, in which artists were awarded honoraria from wealthy patrons or publishers, toward a market model.

Immanuel Kant, Johan Gottlieb Fichte and Georg Wilhelm Friedrich Hegel served to bring these new understandings of art from the periphery to the center of philosophy. Kant (1785) argues that the reprinting of books impinges on the author's agency. His approach understands writing as an act of speech, and reprinting, for Kant, constitutes an act on behalf of the author with or without their permission. Further, Fichte (1793) distinguishes three types of property in relation to books. He contends that ownership of the physical book is conferred on the buyer when the book is sold, and the ideas in the book become the communal property of the buyer and the author insofar as they can be appropriated through intellectual effort. However, the author retains ownership of the form in 
which these ideas are presented (Woodmansee 1994: 51). And, more generally, Hegel contends that the actualization of human will and freedom requires the ownership of property (1974 [1821]: 19-20). These idealist philosophies justified the enactment of copyright laws in various pre-German principalities, and eventually the Berne Treaty of 1886 codified the rights of authors not only over the sale of their creations but, to an extent, over future uses.

Publishers also contended with cultural, economic and legal norms that were at odds with their material interests. Technological innovations including the invention of movable type presses in the late fifteenth century facilitated the larger market for books and new forms of piracy (Eisenstein 1983). Piracy was also encouraged through mercantilist state policies and a public who enjoyed more affordable reading material and benefited from increased public education and literacy (Woodmansee 1994: 46, 49). While during the eighteenth century some German publishers enjoyed monopoly "privileges" mandated by political rulers, they sought increased legal protections for the works that they published (Woodmansee 1994: 45). The conception of the author put forth by German philosophers and poets helped to bring the legal apparatus into line with the interests of the publishers, and even as authors were extended exclusive rights to their works, publishers garnered the most substantial economic benefits from the new protections.

In the Anglo-American context, John Locke's Two Treatises on Government provides a philosophical justification for intellectual property provisions. Locke argues that "every man has a 'property' in his own "person"' and extends this to the products of his labor. Whatever one "removes out of the state of nature" and "mixes" with their labor becomes their property and "excludes the common right of other men" (Locke 1823: 116). Locke contends that property should be determined by labor, but he also argues for the alienability of the products of labor through contracts between, for instance, workers and employers. Women, children, slaves and workers cede the rights to the products of their labor to their master or employer (Locke 1823: 116, 140). Locke does not indicate that his argument can be directly applied to intellectual property. However, the Statute of Anne (1709) brought English copyright law in line with Locke's idea of natural rights and became the foundation for subsequent copyright regimes.

European copyright laws were spread, unevenly, through imperialist conquests. Napoleon's imperial expansion extended French copyright laws to a large swath of Europe. Spain extended its copyright laws to its colonies which covered the works of Spanish writers while special consent was required for the importation of works written in Spanish by colonial subjects (Foster and Shook 1989: 13). Locke's conception of property also travelled to the New World. In fact, Locke's schema served to justify colonial expropriation of seemingly unworked land through the labor of European settlers. British copyright legislation had jurisdiction over their North American colonies until the war of independence, when states began to produce their own laws around intellectual property. The writers of the US constitution enshrined the power of Congress "to promote the process of science and useful arts, by securing for limited times to authors and inventors the exclusive right to their respective writing and discoveries" (US Constitution in Gillespie 2007: 22). On paper, at least, US property laws promote the national interest or common good by means of securing the right to remuneration for authors and inventors. However, until the Copyright Revision Act of 1976, copyright in the US was granted to the first party to publish a text which often placed power in the hands of publishers rather than authors. While Frank Foster and Robert Shook argue that the contemporary law "strengthens the rights of authors and deemphasizes the rights of publishers," this law also extends copyright to 50-75 years after the death of the authors (1989: 18). The extension of copyright ultimately increases the profit margins for publishers by delaying the entry of works into the public domain.

Intellectual property regimes and the ideologies that support them serve to enrich capital often at the expense of writers and the public. The ideology of the author has been used to alienate the product of intellectual property from its producers. It emphasizes a particular type of labor while downplaying the collective and ongoing process of intellectual production. At the same time, it obscures this process from the public and the authors by providing a veneer of empowerment. Historically, the major interests involved in establishing an intellectual property regime in England were competing publishers rather than the authors and artists who served as an ideological foil (Kleiner 2008: 29). Mark Rose goes as far as to suggest "that the London booksellers invented the proprietary author, constructing him as a weapon in their struggle with the booksellers of the provinces" (1993: 41). More recent developments in intellectual property law in the US have extended the longevity of copyright well beyond the life of authors in order to keep works out of the public domain and to reap profits for publishers and media companies. The next section turns from a general ideology critique of authorship and the history of intellectual property, to a particular focus on the labor involved in producing Marx's oeuvre and the works that have been published in the MECW. 


\section{Marx and the Author Function}

The production and collection of Marx and Engels' works is a continuing process that has involved writers, scholars, translators and editors, publishers, political organizations and even states. Before discussing the labor time involved in writing, translating and publishing Marx and Engels' works, I will consider the often controversial intellectual work of determining what counts as Marx's work and what does not. There are a number of ongoing conflicts over what should be included in Marx's oeuvre. These include debates over whether Marx should be given exclusive credit for the authorship of The Communist Manifesto, Louis Althusser's (1970) argument that there is an "epistemological break" between the young and the mature Marx, and Kevin Anderson's recent inclusion of Marx's late unpublished notebooks in Marx on the Margins. The role of determining which of these texts are worthy of inclusion as Marx's work has been made the task of scholars, editors and publishers.

One factor that has contributed to these debates is that Marx, like many writers, wrote in a number of different genres and coauthored works. Julius Smulkstys divides Marx's writings "into eight major categories: poetry and other attempts at writing literature during his youth; philosophical essays; polemical tracts; political pamphlets; correspondence; speeches; newspaper articles; and scientific or economic studies" (1974: 101). Marx penned large manuscripts, such as Capital Volume 1, only some of which were completed and published during his lifetime. In fact, the second two volumes of Capital were completed and published posthumously, largely thanks to Engels. Marx wrote pamphlets and manifestos: The Communist Manifesto, for instance, was written for the Communist League, of which Marx and Engels were active members. It was published in German before being translated into other languages, beginning with the first English edition translated by Helen Macfarlane (Draper 1994). Marx edited the Neue Rheinische Zeitung and was a frequent contributor to German and English language newspapers. The Manifesto was serialized and published in the Deutsche Londoner Zeitung and Marx held a position as a European correspondent for the New York Daily Tribune for which Engels occasionally wrote articles under Marx's moniker (Anderson 2010: 5). Finally, Marx's letters, including his correspondence with Engels, chronicle his political organizing, exchanges with other intellectuals, his family life, poor financial situation and repeated requests for money and commissions. Through his prolific writing, Marx produced an unprecedented critique of the capitalist system of private property while eking out a meager living from royalties, commissions and subscriptions.

While Marx received few royalties during his lifetime, almost all of his writing has since been collected, translated, edited and distributed. This process has involved the labor of writing as well as translating, editing, and publishing processes like typesetting. Christian Fuchs has attempted to calculate the labor involved in producing the MECW by looking specifically at Capital Volume 1, which is reprinted in volume 35 of the MECW. Capital draws on previous works by Adam Smith, David Ricardo and Jean-Baptiste Say as well as taking, as a point of departure, previous work by socialist thinkers such as Robert Owen and Charles Fourier. It also incorporates much of Marx's earlier work, especially The Critique of Political Economy, and is the culmination of myriad drafts and aborted attempts. Putting aside these influences and aborted attempts, Fuchs contends that the text "has primarily been enabled by estimated 20,000 hours of Marx's work, 10,000 hours of [Samuel] Moore and [Edward] Aveling's work and 5,000 hours of Engels' work" (Fuchs 2014). Marx helped to edit and translate a French edition, while the English edition, upon which the MECW version is based, was translated by Moore and Aveling and edited by Engels. It is difficult to determine whether Fuchs' estimations are correct, but he directs attention to the considerable collaborative labor and resources expended in the ongoing creation of Marx and Engels' oeuvre.

The process of publishing a definitive collection of Marx and Engels' work was begun in the 1920s by the Marx scholar David Riazanov with considerable financial support from the Soviet state. The largest collection of Marx's manuscripts and letters was held by the Second International, and Riazanov employed the help of Carl Gruenberg who was the director of the Institute for Social Research at Frankfurt University (and likely the labor of a cadre of students) to make copies of the collection which would become the Marx-Engels Gesamtausabe. Plans for more limited selections that would become the German-language Marx-Engels Werke, and the English-language Marx and Engels Collected Works (to which L\&W now claims ownership) were also devised by Riazanov (Anderson 2010: 248). All of this work took place before L\&W became involved in the process.

The labor involved in translating, copy editing, typesetting and distribution conducted and commissioned by L\&W employees also serves to reproduce and disseminate Marx and Engels' works. Anderson notes: "The most extensive of [Marx's] journalistic writings, those for the Tribune, only became widely available in their entirety in their original English at the end of the 1980s, when they appeared in the Collected Works of Marx and Engels" 
(Anderson 2010: 5). In an official statement the publisher notes: "The work that went into producing [the MECW] involved years of documentary research, collating and organizing, the commissioning of hundreds of translations, and academic work on references and context" (http://www.lwbooks.co.uk/collected_works_statement.html 2014). While much of Marx and Engels' work had already been collated and translated, the continuation of this process by L\&W allows the publisher to assert its ownership of the MECW.

L\&W's claim to the ownership of particular versions of Marx and Engels' work is not based on original authorship and it exemplifies the ways in which copyright alienates the ownership of intellectual property from its creators. L\&W's copyright is based on the status of MECW as a "derivative work." The status of a derivative works can be conferred on translations as well as compilations (http://www.wipo.int/tk/en/resources/glossary.html\#19 2012). In cases where the original work is in the public domain, as is the case with Marx and Engels' writing, the translator gains the sole right to distribute or sell the version that they create. Such a legal claim is also helped if the translator brings together fragments and adds annotations to constitute a reasonably original work, because The World Trade Organization's (1994) Agreement on Trade Related Aspects of Intellectual Property Rights (TRIPS Agreement) and the (1996) WIPO Copyright Treaty have extended the label of "derivative work" to compilations and collections. However, translators and workers involved in producing compilations, like authors, generally sell their labor to publishers that have the capacity to profit from the sale of the work.

Existing copyright regimes do not acknowledge the history of collaborative production, maintenance and funding of Marx and Engels' texts when attributing the right to distribute and profit from $\underline{\mathrm{MECW}}$. In some instances, L\&W claims ownership of texts under contract with translators while in others their claim can only be based on the book's status as compilation with added notations. Ultimately, this means that L\&W can claim legal rights to the $\underline{\mathrm{MECW}}$ and reap the profits of labor contributed by Marx, Engels, Moore, Aveling, Riavanov and many others who have contributed to the production of Marx's oeuvre. At the same time, they do not recognize the work required to produce and archive these texts in the MIA. L\&W's claim is highly selective in terms of which aspects of the production and reproduction of $\underline{\mathrm{MECW}}$ are recognized as the basis for ownership.

\section{| Digital Production and Intellectual Property}

Despite the long history of collaboration that produced the collection, L\&W is deploying its copyright claim to impede new avenues for digital reproduction at the expense of public access. With the advent of digital media, Tarleton Gillespie contends that copyright now faces "a technology that dramatically reimagined how and by whom culture is produced, sold, distributed and consumed" (Gillespie 2007: 4). As we have seen, intellectual property regimes emerged at the end of the eighteenth century when the primary technology for the reproduction and distribution of manuscripts was the printing press, authors and publishers were attempting to secure monopoly rights over particular texts, and European states were attempting to foster domestic markets while engaging in imperialist expansion. L\&W's claim to the ownership of Marx and Engels' work is situated within new technological, economic, cultural and political constellations. The internet has lowered the cost of entry for prospective media producers, enabling forms of networked and online collaboration, and reduced the cost of copying, archiving and distributing information.

Scholars such as Clay Shirky celebrate the productivity of new collaborative and voluntary online projects while downplaying the labor involved in their reproduction. In his (2010) Cognitive Surplus, Shirky identifies the productive powers made available through increased leisure time, networked technologies and intrinsic motivations. He argues that since the end of the Second World War in developed countries there has been an increasing "amount of unstructured time cumulatively available to educated populations" (Shirky 2010: 5). The internet opens the way for these billions of collective leisure hours to be put toward creative and scientific endeavors. However, Shirky does not see these endeavors as involving labor. He asks, "what if the contributors aren't workers? What if they really are contributors, quite specifically intending their contributions to be acts of sharing rather than production?" (Shirky 2010: 58). People, like those involved in curating MIA, are willing to contribute their time and effort to causes and projects without remuneration. But, positing productive activities as solely "acts of sharing" avoids questions about what happens when these projects run afoul of strategies of accumulation. The rhetoric of MIA's volunteer page explicitly acknowledges that the contributions are both voluntary and a type of labor: 
Volunteers come into the project to do work on what they like - there is no top down or centralized planning structure... We are all involved with activities other than building this archive, from our day-jobs (and we hold a diverse array of them!) to being with our families and friends. The MIA has been built simply by workers who give a few minutes of labor at the end of the day (http://www.marxists.org/admin/volunteers/index.htm 2014).

In opposition to Shirky's approach, a focus on the labor involved in these projects can provide collaborative projects like the MIA with a legal and moral claim to collective ownership of their products.

Autonomist Marxists point to the prominence of "immaterial labor" in digital production. While this approach attempts to address the collaborative character of this work, it eclipses the specific types of labor that are required for the reproduction of projects like MIA. Scholars such as Maurizio Lazzarato argue that immaterial labor evades classical economic strategies of measurement, and Michael Hardt and Antonio Negri suggest that the "temporal unity of labor as the basic measure of value today makes no sense" (Lazzarato 1996: 113; Hardt and Negri 2004: 145). While MIA relies on the contributions of volunteers from around the world who collaborate remotely and in their own time via the internet, it is possible to identify the particular types of work and the labor time required to produce and archive specific texts. In addition to the technical work that goes into maintaining MIA's website and archives, volunteers engage in transcribing/publishing, translating, proofreading and researching. Before the version of Capital Volume 1 based on the MECW was removed from MIA's website, the site listed Bert Schultz as the transcriber, Brian Baggins and Andy Blunden as responsible for the html markup, and Andy Blunden as a proof reader. In response to a question about the time necessary to archiving a text, Blunden noted that "No way have we ever worked out the hours etc." (2014). He further suggested: "Why don't you just do a test run yourself. Pick a book. Scan it. OCR it. Proofread and correct it, then convert it to HTML" (Blunden 2014). The concept of immaterial labor fails to account for the labor time contributed by volunteers who perform these specific tasks for MIA. Labor is always material because it consists of human cognition, communication and bodily activity that "changes the state of real world systems" (Fuchs 2008: 103).

In contradistinction to the autonomist approach to "immaterial labor," the extension of Marx's labor theory of value provides an understanding of the concrete labor involved in intellectual production. In Marx's formulation, the value of a commodity is made up of its raw materials (constant capital), necessary labor (variable capital), and the surplus value created by labor (Fuchs 2008: 175):

$$
\mathbf{V}=\mathbf{c}+\mathbf{v}+\mathbf{s}
$$

The cost of each paper copy of a volume of the MECW sold by L\&W for $£ 50$ or the whole series sold for $£ 1,000$ includes the cost of raw materials, the labor of printers and other workers, and a margin for profit (though, importantly not the cost of Marx, Engels, Moore or Aveling's labor) (http://www.lwbooks.co.uk/books/archive/ marx_offer.html 2014). Once the first edition of MECW had been produced, the organic composition of capital increases for subsequent print runs. Once the work of writing, collecting, translating, editing and annotating the texts in the MECW is completed, the only costs involved in reproducing their works are those involved in making and distributing copies. Digital publishing has changed the economic equation for the reproduction of texts.

The process of reproduction is made considerably cheaper by digital technologies whereby, after the initial labor involved in formatting a text and posting it online, the cost of making copies is reduced to almost nothing. Unlike the printed volumes of the MECW, the cost of each digital copy of Marx's texts is infinitesimally small. MIA is able to provide free and unfettered content because of the reduced cost of online hosting, volunteer labor, and collaborative forms of editing, translating and curating enabled through the internet. That is not to say that labor, infrastructure and energy costs are not involved in making these texts available online, but that digital distribution considerably decreases costs for MIA.

Faced with this competition, L\&W has invoked copyright to create an artificial scarcity and maintain the commodity status of Marx and Engels' work. The scarcity and cost imposed by L\&W has the effect of limiting access to those people who either have the considerable sum to spend on the books for their private collection or who have access to academic libraries. Volunteer organizations like MIA lack economic resources compared to publishing companies, which likely contributes to their policy of removing contested material without recourse to the courts. However, a number of petitions and mirror sites emerged in response to L\&W's actions. One petition calling for free online access to $\underline{\mathrm{MECW}}$ received more than 2500 signatures from around the world (http://www.change. org/en-GB/petitions/lawrence-and-wishart-allow-marx-s-and-engels-s-writings-to-remain-in-the-public-domain 2014). MIA also encourages others to copy and distribute their material. The organization suggests that volunteers 
and users make eBook versions of texts from their archives, make "mirror" sites, distribute DVD's, or print out texts (http://www.marxists.org/admin/volunteers/index.htm 2014). As a result, it is almost impossible to remove the material originally hosted by MIA from the internet. At the current juncture, struggles over copyright and digital media could result in a further retrenchment of copyright through legal and technological mechanisms or they could be leveraged to address the concerns of knowledge workers and to support increased public access to information.

\section{| Alternatives to the Current Intellectual Property Regime}

Marx and Engels' works have been dragged into contemporary struggles over copyright. While Fuchs stresses the importance of looking at the labor of Marx, Engels and others involved in producing these works, he argues that "claiming the MIA is stealing information from L\&W is just as absurd and misplaced as claiming that L\&W is stealing information from Marx and Engels because the whole idea of a copyright on Marx and Engels" works is absurd" (Fuchs 2014). At the very least, L\&W's role in publishing books for library shelves and private collections should not impinge upon the availability of Marx and Engels' work online. In the meantime, the controversy over MECW allows us to pose questions about alternative ways to produce, archive and distribute knowledge.

There are a number of innovative institutional models for reconceptualizing and reorganizing knowledge production and archives. Mario Biagioli contends that large-scale multi-authorship in the natural sciences renders untenable the idea of the "scientist as the person who had the idea, did the work, wrote the paper, and took credit and responsibility for it" (2003: 261). In response to this crisis of scientific authorship, some journals, particularly in the field of biomedicine, have attempted to narrowly define authorship in terms of "intellectual contributions" to the exclusion of other forms of labor involved in scientific production. Hugh Gusterson explains that, in such an approach to knowledge production, "intellectual value, or capital, tends to behave in the same way as material value in large capitalist institutions: it is extracted from those on the bottom, who create it through labor, accruing as wealth to those on the top..." (2003: 284). Biagioli identifies an alternative approach at the Collider Detector at Fermilab physics laboratory which is characterized by a "labor mentality" (2003: 207). In this model all employees who contribute labor in a research community, including technical staff, are listed as authors, even for publication on which they do not directly work. This particular model relies on the shared physical space of the laboratory, multimillion-dollar equipment and government grants. Nonetheless, it shows how communities can allocate rights and responsibilities for knowledge production without discriminating between different types of labor. Such a model would recognize the labor which goes into reproducing and archiving texts online.

In some respects, the labor mentality model parallels strategies for Community Intellectual Rights (CIR) in socalled "traditional communities." Peter Jaszi and Woodmansee suggest that CIR, which does not rely on the fiction of a single author or inventor, is gaining traction in Latin America and parts of Africa as ways to claim rights over the production and maintenance of community knowledge (2003: 215). CIR seeks to protect the ongoing process of knowledge creation rather than assigning rights to finished products and individual creators. It attributes knowledge production to dynamic and changing communities of producers that should have a collective claim to how knowledge is produced, stored, distributed and used. The very different types of collaborative intellectual production involved in large-scale scientific laboratories and traditional cultures are responses to the crisis of the author and the limits of current copyright regimes for addressing collective intellectual production. The labor mentality model and CIR recognize the social character of knowledge production, but they also provide means through which particular communities of producers are able claim rights to the processes and the products of their labor.

Another example is provided by the Roy Rosenzweig Center for History and New Media (CHNM) at George Mason University. The center "uses digital media and technology to preserve and present history online, transform scholarship across the humanities, and advance historical education and understanding" (http://chnm.gmu.edu/ about/ 2014). It is a collaborative center that produces free software for historians and educators under Creative Commons licensing as well as allowing members to pursue their own research interests. CHNM provides a model for digital archiving, but it is able to draw on resources that are unavailable to many archiving projects; it relies on its institutional affinity for access to necessary infrastructure and the scholarly reputation of its members in order to attract grants.

Both CHNM and MIA use Creative Commons licensing, but Creative Commons has important limitations. Supporters of Creative Commons such as James Boyle, Lawrence Lessig and Yokai Benkler argue for reforms to 
copyright law while maintaining the necessity of private property. Boyle warns that "bad policy may lock up our cultural heritage unnecessarily, leave it to molder in libraries, forbid citizens to digitize it, even though the vast majority of it will never be available publicly and no copyright owner can be found (2008: 246). Lessig suggests that society faces a number of choices about how its values can be maintained through their inscription into both law and digital technologies. He advocates "free culture" which allocates intellectual property rights while allowing others access in order to create and innovate, as opposed to "permission culture" wherein "creators only get to create with the permission of the powerful” (Lessig 2004: xvi). For Lessig, such a model is presented by Creative Commons (Lessig 2006: 199). Benkler and Lessig limit the idea of peer production to digital products which they categorize as "nonrival" goods. Further, while Creative Commons licensing makes intellectual property rights more flexible, it reinforces the regime of individual copyright from which those who own property are able to continue to draw rent. Creative Commons licenses can account for collaborative projects, but, in order to operate within current intellectual property regimes, they continue to perpetuate the metaphors of authorship and originality.

Even approaches that stipulate the end of private property as an ultimate goal must address the need to remunerate a growing number of knowledge workers and provide public access to informational goods in the shortterm. Dmytri Kleiner (2011) focuses on the collaborative nature of production and the goal of building collective resources. He suggests "venture communism" as a way for information workers to accrue resources and make their work available to a community of users in order to undermine corporate forms of control and exploitation. Kleiner advocates having two sets of rules: one set for "venture communes" who collectively own the rights to content and infrastructure and can accumulate wealth by adding their labor to this pool; and, another set of rules that prevents the exploitation of the commons by companies that wish to extract rent. Further, he points to the materiality of digital and "nonrival" goods: "Computers and networks, as well as developers and their places of work and residence, are all very much material and all require material upkeep” (Kleiner 2011: 21). As such, Kleiner, who is part of such a community, hopes this strategy will allow communally organized knowledge workers to accumulate the resources and build the infrastructure needed to challenge the existing mode of production.

\section{Conclusion}

These contemporary examples of models for collective knowledge production and archiving respond to an ongoing crisis of the concept of authorship and the limits of intellectual property regimes. By sketching the historical production of Marx and Engels' oeuvre, I hope to have shown that when we read their words today, they are mediated by the labor of translators, editors, interpreters and technical workers. Ownership of their work can no longer be justified by original authorship. L\&W's claim to own these works does not recognize the majority of the labor time that has gone into reproducing these texts and contradicts the justifications for copyright, including the supposed incentives for producing or distributing knowledge. Ultimately, L\&W's recourse to copyright law in the case of the works collated in MECW comes at the cost of public access. For now, MIA may be able to draw on its nonprofit status and the affordances of networked technologies in order to produce versions of Marx and Engels' work that will not raise the ire of other publishers. However, sustainable alternatives to current intellectual property regimes will need to provide for the material needs of knowledge workers by collectivizing the infrastructure of knowledge production and archiving, while continuing to increase public access to informational products.

\section{References}

Althusser, Louis and Étienne Balibar. [1968] 1970. Reading Arrow, Kenneth. 1996. "The Economics of Information: An Capital. Translated by B. Brewster. London: New Left Books. ～Exposition.” Empirica. 23(2) 119-128.

Anderson, Kevin. 2010. Marx on the Margins: On Nationalism, Benkler, Yokai. 2006. The Wealth of Networks: How Social Ethnicity, and Non-Western Societies. Chicago: University of Production Transforms Markets and Freedom. New Haven: Chicago Press. Yale University Press. 
Biagioli, Mario. 2003. Rights or Rewards: Changing Frameworks of Scientific Authorship. Scientific Authorship: Credit and Intellectual Property in Science. Edited by M. Biagioli, and P. Galison. New York: Routledge.

Blunden, Andy. 2014. Personal correspondence.

Boyle, J. 2008. The Public Domain: Enclosing the Commons of the Mind. New Haven: Yale University Press.

Draper, Hal. 1994. The Adventures of the Communist Manifesto. Berkeley: Center for Socialist History.

Eisenstein, Elizabeth. 1983. The Printing Revolution in Early Modern Europe. Cambridge: Cambridge University Press.

Engels, Frederick. [1847] 1947. The Principles of Communism. Translated by P. Sweezy.<https://www.marxists.org/archive/ marx/works/1847/11/prin-com.htm>.

Foster, Frank and Robert Shook. 1989. Patents, Copyrights \& Trademarks. New York: Wiley.

Foucault, Michel. [1969] 1977. "What is an Author?" Translated by D. Bouchard and S. Simon Language, Counter-Memory, Practice. Edited by D. Bouchard. Ithaca: Cornell University Press.

Fuchs, Christian. 2014. "Lawrence \& Wishart vs. The Marxists Internet Archive: The Blindness of the Copyright Left." <http://fuchs.uti.at/1123/>. Accessed May 7, 2014.

Fuchs, Christian. 2008. Internet and Society: Social Theory in the Information. New York: Routledge.

Hardt, Michael and Antonio Negri. (2004). Multitude. Penguin. New York, NY.

Hegel, Georg Wilhelm Friedrich. (1974). Hegel's Philosophy of Right, with Marx's Commentary: a Handbook for Students. (Ed.) Kainz, P. Martinus Nijhoff. The Hague, Netherlands.

Gillespie, Tarleton. 2007. Wired Shut: Copyright and the Shape of Digital Culture. Cambridge: MIT Press.

Gusterson, Hugh. 2003. "The Death of the Authors of Death: Prestige and Creativity among Nuclear Weapons Scientists." Scientific Authorship: Credit and Intellectual Property in Science. Edited by M. Biagioli, P. Galison. New York: Routledge.

Jaszi, Peter and Martha Woodmansee. 2003. "Beyond Authorship: Refiguring Rights in Traditional Culture and Bioknowledge." Scientific Authorship: Credit and Intellectual Property in Science. Edited by M. Biagioli, P. Galison. New York: Routledge.

Kant, Immanuel. 1785. "On the Injustice of Reprinting Books." Berlinische Monatsschrift. Berlin.

Kleiner, Dmytri. 2010. Telekommunist Manifesto. Notebooks.<http:// telekommunisten.net/ the-telekommunist-manifesto/>.

Lawrence \& Wishart. 2014. <http://www.lwbooks.co.uk>. Accessed May 7, 2014.
Lessig, Lawrence. 2006. Code: Version 2.0. New York: Basic Books.

Lessig, Lawrence. 2004. Free Culture: How Big Media Uses Technology and the Law to Lock Down Culture and Control Creativity. $<$ http://www.free-culture.cc/ $>$.

Locke, John. 1823. Two Treatises on Government. Edited by Hay, R. London: McMaster University Archive of the History of Economic Thought.

Marx, Karl and Frederick Engels. 1988. Collected Works. Vol. 43: Letters. Lawrence \& Wishart. London, UK.

Marx, Karl and Frederick Engels. 1974. Collected Works. Vol. 35: Capital: A Critique of Political Economy, Volume 1. Edited by F. Engels. Translated by S. Moore and E. Aveling, London: Lawrence \& Wishart.

Marx, Karl and Frederick Engels. 1967. The Communist Manifesto. Translated by S. Moore. Baltimore: Penguin.

Marxists Internet Archive. <http://marxists.org/>. Accessed May 7, 2014.

Marxist scholars and activists around the world. "Petitioning Lawrence and Wishart: Allow Marx's and Engels's writings to remain in the public domain." < http://www.change.org/ en-GB/petitions/lawrence-and-wishart-allow-marx-s-and-engels-s-writings-to-remain-in-the-public-domain >. Accessed June 19, 2014.

Rose, Mark. 1993. Authors and Owners: The Invention of Copyright. Cambridge: Harvard University Press.

World Intellectual Property Organization. 2012. "Glossary." <http://www.wipo.int/tk/en/resources/glossary.html\#19>. Accessed June 19, 2014.

Smulkstys, Julius. 1974. Karl Marx. New York: Twayne Publishers.

Woodmansee, Martha. 1994. The Author, Art, and the Market: Rereading the History of Aesthetics. New York: Columbia University Press. 
